\title{
Correlation Between Medical Information Completeness and Accuracy of The Diagnosis Code for Upper Respiratory Tract Infection and Hypertension Based on ICD-10 in Medical Record at Cibening Health Center
}

\author{
Ahmad Muchlis ${ }^{1 *}$, Rifa Aulia Ramadhanty ${ }^{2}$ \\ 1) Department of Bioethic-Medicolegal, Faculty of Medicine and Health, Universitas Muhammadiyah Jakarta, Indonesia \\ 2) Medical Study Program, Faculty of Medicine and Health, Universitas Muhammadiyah Jakarta, Indonesia \\ *Corresponding author: dr.muchlis@gmail.com
}

\begin{abstract}
Background: Completeness of patient medical information in medical records is one indicator in assessing the quality of health services. Complete and accurate medical records contribute to the accuracy of medical staff in making a diagnosis so that they can determine the correct diagnosis code according to the ICD-10 guidelines. A good medical record shows that a doctor or other medical staff has carried out their duties by the demands of their profession as stated in the Medical Practice Law No.29 of 2004. Purposes: To find out there is or not a correlation between the medical information completeness and the accuracy of the diagnosis code for upper respiratory tract infection and hypertension based on the ICD-10 in the medical record documents of outpatients at the Cibening Health Center in 2019. Method: The method used in this study is observational analytic with a crosssectional study design. The population of this study was outpatient medical records with a diagnosis of upper respiratory tract infection and hypertension at the Cibening Health Center in 2019. The sampling technique used a simple random sampling technique with a sample size of 100 . Results: Out of obtained 71 complete medical record (71\%) filling in medical records, 64 medical records $(64 \%)$ were accurate in giving ICD-10 codes, 63 medical records $(88.7 \%)$ with complete medical information had accurate diagnosis codes in comparison with 8 medical records $(11.3 \%)$ which were complete but inaccurate diagnosis code. Conclusion: With a p-value of 0.000 , there is a significant correlation between the completeness of medical information and the accuracy of the diagnosis code for Upper Respiratory Tract Infection and Hypertension based on ICD-10.
\end{abstract}

Keywords: accuracy of icd-10 code, medical information, outpatient

\section{INTRODUCTION}

Health service facilities are crucial and important component of community needs that must be met immediately. As the executor of the District / City Health Office, Health Center is present as one of the firstlevel health service facilities that play a role in improving the optimal degree of public health by improving the quality of its services, both in the form of medical services and non-medical services. One of the indicators for assessing the quality of good health services is the quality of medical records (MR) completeness because medical records completeness will make it easier for other medical personnel to carry out the service process for patients while in health service facilities (1).

In fact, in health service facilities in Indonesia there are still many medical record documents that have not been completed completely, according to 
Wirajaya and Nuraini (2019), there are three factors that affect the incompleteness of medical records in health service facilities, including human resources (lack of knowledge, discipline and motivation of a doctor or other medical personnel in filling and returning medical records), tools (availability of medical record room and checklist sheet stating complete or incomplete medical records) and methods (work procedures that are not prudent and do not have fixed guidelines and a reward system or punishment in administering medical records). Incomplete medical records will contain medical information that is not continuous and difficult to reidentify (2).

According to Hampton in Cooke (2012), the completeness of medical records (results of history taking, physical examination and supporting examinations) contributes to the accuracy of medical personnel in making a diagnosis that will assist coding officers in determining the diagnosis code based on the disease classification set by WHO, namely ICD-10 (3). The function of the accuracy of the diagnosis code based on ICD-10 is to facilitate health service facilities in the service process, data storage, data reporting, and to determine the amount of patient financing during service, so that patients can make payments according to the actions that have been obtained, thereby reducing the risk of loss from both parties, either from the patient or health service facilities (4). According to research by Maisharoh (2020), there is a relationship between the clarity and accuracy of writing the diagnosis with the accuracy of the diagnosis coding at Pelompek Kerinci Community Health Center $(p$-value $=0.001)$. Of the 87 outpatient medical records at Puskesmas Pelompek Kerinci, it was found that 40 medical records $(46.0 \%)$ were incorrect in coding the diagnosis, while 47 medical records $(54.0 \%)$ were incorrect in coding the diagnosis. One of the causes of inaccuracy in the diagnosis code is the unclear and inaccurate writing of the diagnosis made by doctors or other health professionals in medical records (5).

Upper Respiratory Tract Infection and Hypertension are among the ten cases of disease with the highest number of outpatient cases at the Bogor City Health Center. Previously, no research or publication related to the accuracy of the diagnosis code for Upper Respiratory Infection and Hypertension was found at Cibening Health Center (6). That is what prompted the author to conduct this study regarding the relationship of completeness of medical information with the accuracy of the diagnosis code for upper respiratory tract infections and hypertension based on ICD-10 in the medical record documents of outpatients at the Cibening Public Health Center in 2019.

\section{METHODS}

This research is analytic observational with cross sectional approach. The population of this study was outpatient medical records with a diagnosis of Upper Respiratory Tract Infection and hypertension at the Cibening Public Health Center in 2019. The sample used was 100 medical records. The sampling method in this research is a simple random sampling technique. The data obtained were then analyzed by univariate and bivariate analysis. Univariate analysis was used to obtain a complete picture of medical information and the accuracy of the diagnosis code of disease cases on the medical record sheet, data were presented in frequency distribution, while bivariate analysis was used to analyze the presence or absence of a 
relationship using the chi-square statistical test. This analysis was carried out using statistical software (7). This research has received an ethical clearance letter from the research ethics commission of the Faculty of Medicine and Health, University of Muhammadiyah Jakarta by letter number 09/F.7.3-UMJ/IX/2020.

\section{RESULT}

\section{Completeness of Medical Information}

The completeness percentage of medical information illustrates that the level of completeness of medical records with complete categories is $71(71 \%)$ and medical records with incomplete categories is 29 (29\%), for more details it is presented in the following table:

Table 1. Distribution of Completeness of Medical Information

\begin{tabular}{lcc}
\hline $\begin{array}{c}\text { Completeness } \\
\text { of Medical } \\
\text { Information }\end{array}$ & $\begin{array}{c}\text { MR amount } \\
(\mathbf{n = 1 0 0 )}\end{array}$ & $\begin{array}{c}\text { Percentage } \\
(\boldsymbol{\%})\end{array}$ \\
\hline Complete & 71 & 71 \\
\hline Incomplete & 29 & 29 \\
\hline
\end{tabular}

This study analyzed items of outpatient medical information at the Cibening Health Center on the results of anamnesis, physical examination, supporting examinations and diagnosis, with the following results. Based on table 2, it was found that the level of medical information completeness in medical records on anamnesis results, physical examination, supporting examination, and diagnosis are $90 \%, 75 \%, 68 \%, 71 \%$.

Based on table 3, out of 100 outpatients medical records studied, it was found that $64(64 \%)$ medical records were accurate in ICD-10 coding and $36(36 \%)$ medical records were inaccurate in coding ICD-10.
Table 2. Distribution of Sub Variable Completeness of Medical Information

\begin{tabular}{lcc}
\hline $\begin{array}{c}\text { Sub Variable } \\
\text { Completeness } \\
\text { of Medical } \\
\text { Information }\end{array}$ & $\begin{array}{c}\text { Complete } \\
\mathbf{n}(\%)\end{array}$ & $\begin{array}{c}\text { Incomplete } \\
\mathbf{n}(\%)\end{array}$ \\
\hline Anamnesis & $90(90)$ & $10(10)$ \\
\hline $\begin{array}{l}\text { Physical } \\
\text { examination }\end{array}$ & $75(75)$ & $25(25)$ \\
\hline $\begin{array}{l}\text { Supporting } \\
\text { examination }\end{array}$ & $68(68)$ & $26(68)$ \\
\hline Diagnosis & $71(71)$ & $29(29)$ \\
\hline
\end{tabular}

ICD-10 Diagnostic Code Accuracy and Inaccuracy

Table 3. Distribution of ICD-10 Diagnostic Code Accuracy

\begin{tabular}{lcc}
\hline $\begin{array}{l}\text { Filling in the } \\
\text { ICD-10 Code }\end{array}$ & $\begin{array}{c}\text { MR amount } \\
(\mathbf{n = 1 0 0})\end{array}$ & $\begin{array}{c}\text { Percentage } \\
(\boldsymbol{\%})\end{array}$ \\
\hline Accurate & 64 & 64 \\
\hline Inaccurate & 36 & 36 \\
\hline
\end{tabular}

Table 4. Code Classification Inaccuracies ICD10

\begin{tabular}{lcc}
\hline Classification & $\begin{array}{c}\text { MR amount } \\
(\mathbf{n = 3 6 )}\end{array}$ & $\begin{array}{c}\text { Percentage } \\
(\boldsymbol{\%})\end{array}$ \\
\hline $\begin{array}{l}\text { Only up to the } \\
\text { third character }\end{array}$ & 17 & 47.22 \\
\hline Incorrect code & 8 & 22.22 \\
\hline Not coded & 11 & 30.56 \\
\hline
\end{tabular}

\section{Relation of Completeness of Medical Information to Accuracy of ICD-10 Codes}

Based on table 5, medical records documents with complete medical information and accurate diagnosis codes were 61 documents (88.7\%), medical records documents with complete medical information but inaccurate code were 8 documents (11.3\%), medical records documents with incomplete medical information and accurate diagnosis code were 1 document (3.4\%), and medical records documents whose medical information 
was incomplete and the diagnosis code was inaccurate were 28 documents $(96.6 \%)$.

Table 5. The Relationship of Completeness of Medical Information to the Accuracy of ICD-10 Code

\begin{tabular}{lccc}
\hline $\begin{array}{c}\text { Completeness } \\
\text { of Medical } \\
\text { Information }\end{array}$ & $\begin{array}{c}\text { ICD-10 Code Accuracy } \\
\text { Accurate } \\
\mathbf{n}(\%)\end{array}$ & $\begin{array}{c}\text { Inaccurate } \\
\mathbf{n}(\%)\end{array}$ & value \\
\hline Complete & 63 & 8 & \\
& $(88.7 \%)$ & $(11.3 \%)$ & 0.000 \\
Incomplete & 1 & 28 & \\
\hline
\end{tabular}

\section{DISCUSSION}

Incomplete medical information will have an impact on the quality of medical record documents and may affect the accuracy of the code. This is in accordance with the results of research by Warsi Waryani et al (2019), the completeness of writing medical information on each medical record has an important role in determining accurate code through a diagnosis set by a doctor. Other research that supports the appropriate results is also found in Linda Widyaningrum's (2020) study, that in addition to the coder's ability to code a diagnosis, the patient's medical information on medical records has a role in helping coders determine the correct ICD code (8).

In this study, the completeness of the medical information studied included the results of the history, physical examination, supporting examinations and diagnosis. This refers to Hampton's research in Cooke (2012), which revealed that to obtain the correct clinical diagnosis for a patient is to know the patient's history and carry out a physical examination and appropriate supporting examinations. Based on the results of a study conducted on 80 patients, 66 patient diagnoses $(82.5 \%)$ could be confirmed precisely and accurately only by obtaining patient history, while 80 patient diagnoses $(100 \%)$ could be confirmed appropriately after adding physical examination and supporting examination. According to him, building good communication between doctor-patient and the ability of a doctor are the key's for a doctor to make it easier for them to take patient's history and make decisions to take action and determine a patient's diagnosis. A careful history taking will lead to $82.5 \%$ accuracy of patient's diagnosis. Meanwhile, the doctor's ability to carry out physical examinations and appropriate supporting examinations of patients will add $17.5 \%$ to the accuracy of the diagnosis (3).

The completeness of medical information in the medical record will make it easier for coders to code the ICD-10 diagnosis correctly, because the coding officer does not only look at the diagnosis, but also need to see the medical information contained in each sheet of medical records written by the doctor to produce an accurate code (9). This is in accordance with PMK No. 269 of 2008 concerning medical records that the responsibility for writing medical records is the responsibility of a doctor or dentist (10).

Based on table 3, out of 100 outpatients medical records studied, it was found that 64 (64\%) medical records were accurate in ICD-10 coding and 36 (36\%) medical records were inaccurate in coding ICD-10. The accuracy of filling in the diagnosis code on the medical records is crucial, because if the diagnosis code is not correct or not in accordance with the ICD10 it can cause a decrease in the service quality assessments in the health agency and can affect data, report information, and the accuracy of payment rates for services. The low health service rate will certainly be detrimental to the health institution. On the other hand, the high health service rate will give the impression that the health agency has benefited from the difference in rates so 
that it is detrimental to health insurance administrators and patients.

The factor that causes the inaccuracy of the ICD-10 code in this study is the code that should have been coded up to the fourth character, only coded up to the third character, it was found that the ICD code was not filled in and the code was wrong. Based on table 4, it shows that the ICD code which is only coded up to the third character is the highest factor that causes the inaccuracy of the diagnosis code on outpatient medical record (11). The results of this study are quite in line with the research conducted by Maisharoh (2020) conducted at the Pelompek Kerinci Community Health Center, it was found that 47 medical records $(54.0 \%)$ was declared accurate in the coding of ICD-10 diagnoses while 40 medical records (46.0\%) was declared inaccurate. The code inaccuracy on the medical records is affected by the incomplete medical information contained therein so that the coder can only code the diagnosis up to the third character (5).

Based on table 5, obtained from 100 medical records documents studied, medical records documents with complete medical information and accurate diagnosis codes were 61 documents (88.7\%), medical records documents with complete medical information but inaccurate code were 8 documents (11.3\%), medical records documents with incomplete medical information and accurate diagnosis code were 1 document (3.4\%), and medical records documents whose medical information was incomplete and the diagnosis code was inaccurate were 28 documents (96.6\%).

In the statistical test results, the chi square test is fulfilled and the $\mathrm{p}$-value $=$ 0.000 ( $\mathrm{p}$-value $=<\alpha=0.05$ ) is obtained, which means that there is a significant relationship between the completeness of medical information and the accuracy of the diagnosis code for Upper Respiratory Tract Infection and hypertension based on ICD10 in the record document. medical outpatient at Cibening Health Center in 2019.

The results of this study are in line with the research of Warsi Waryani et al (2019) at Dr. Moewardi who stated that, complete medical information has a better quality of diagnosis code $(73.80 \%)$ compared to incomplete medical information (36.00\%) with 1.54 times better probability of diagnosis code quality than poor quality (12).

\section{CONCLUSION}

There is a significant relationship between the completeness of medical information with the accuracy of the diagnosis code for Upper Respiratory Tract Infection and Hypertension based on ICD-10 in the medical record documents of outpatients at the Cibening Health Center in 2019. Based on the results of statistical tests with the chi square test, $\mathrm{p}$-value $=0.000(\mathrm{p}$ - value $=<\alpha$ $=0.05)$.

Researchers suggest that doctors and other health workers should immediately complete medical record documents, especially sheets relating to the classification and coding of diseases after that patient leaves the health service facility, and the coder should improve communication and cooperation with parties who contribute to filling the record, if the coder has difficulty reading the diagnosis and medical information in the medical record.

\section{ACKNOWLEDGMENT}

The authors would like to thank the Cibening Health Center for given permission to take a 100 samples and make this process done well. We would also like 
to thank to Muhammadiyah University of Jakarta and all friends who have helped and supported this research.

\section{CONFLICT OF INTEREST}

Authors state have no conflict of interest, and no affiliation or connection to or with any entity or organization, which may raise a question of bias in discussion and conclusion of the manuscript.

\section{REFERENCES}

1. Menteri Kesehatan RI. Permenkes RI No. 43 tahun 2019 Tentang Pusat Kesehatan Masyarakat. 2019 p. 130.

2. Wirajaya MK, Nuraini N. Faktor Faktor yang Mempengaruhi Ketidaklengkapan Rekam Medis Pasien pada Rumah Sakit di Indonesia. J Manaj Inf Kesehat Indones. 2019;7(2):165.

3. Cooke G. Is it true that "A careful history will lead to the diagnosis $80 \%$ of the time"? Aust Fam Physician. 2012;41(7):534.

4. Hanafiah Y, Amir A. Etika Kedokteran \& Hukum Kesehatan. 5th ed. Vol. 5, EGC. Jakarta: EGC; 2016. 354 p.

5. Maisharoh EJ. Hubungan Kejelasan dan Kelengkapan Penulisan Diagnosa dengan Ketepatan Pengkodean Berdasarkan ICD-10 Pada Berkas Rekam Medis Rawat Inap di RSUP dr. M.Djamil Padang. STIKES Dharma Landbouw Padang. 2020;1(1):43-54.

6. Dinas Kesehatan Kota Bogor. Profil Kesehatan 2018. Dinas Kesehatan Kota Bogor. 2018. 112 p.

7. Notoatmodjo S. Metodologi Penelitian Kesehatan. In Jakarta: Rineka Cipta; 2018.
8. Ningrum LW. Correlation of Complete Medical Information With Accuracy Diagnosis Code of Urinary Tract Infection At Sebelas Maret Hospital. J Ris Kesehat. 2020;9 (1):78-82.

9. WHO. International Statistical Classification of Diseases and Related Health Problems, 10th Revision ICD-10 : Tabular List. In: Ganeva. 2016. p. 332-45.

10. Menteri Kesehatan RI. Permenkes RI No. 269/Menkes/Per/III/2008. Menteri Kesehatan RI; 2008 p. 7.

11. WHO. International Statistical Classification of Diseases and Related Health Problems, 10th Revision ICD-10: Alphabetic Index. Vol. 3, Ganeva. 2016. p. 841.

12. Maryati W, Rahayuningrum IO, Ismayani A. Quality of medical information determine the quality of diagnosis code. Int J Public Heal Sci. 2019;8(3):326. 